\title{
PENGARUH LABORATORIUM VIRTUAL TERHADAP PRESTASI FISIKA PADA POKOK BAHASAN LISTRIK STATIS
}

\author{
Eka Maryam \\ Universitas Bina Insan Lubuklinggau \\ ekamaryam996@gmail.com
}

\begin{abstract}
Abstrak
Penelitian ini dilakukan pada tahun pelajaran 2017/2018 di kelas XII Madrasah Aliyah Al Muhajirin Tugumulyo. Tujuan penelitian ini untuk mengetahui pengaruh laboratorium virtual Physics Education Technology terhadap hasil belajar fisika siswa. Populasi yang digunakan penelitian ini seluruh siswa kelas XII IPA MA Al Muhajirin Tugumulyo dengan jumlah 95 siswa. Sedangkan sampel penelitian ini diambil mengunakan teknik convenience sampling, yakni pengontrolan sampel berupa sampel sepadan. Sampel yang digunakan penelitian ini kelas XII Ibnu Miskawaih sebagai kelas yang diberikan treatment, dan kelas XII Al Idris sebagai kelas pembanding. Teknik analisis data menggunakan analisis inferensial, yakni uji prasyarat dan uji t statistik. Hasil penelitian didapatkan nilai rata-rata kelas kontrol 65 pre-test dan post-test 68 , artinya mengalami kenaikan hasil belajar sebesar $24 \%$. Sedangkan pada kelas eksperimen nilai rata-rata hasil belajar pada pre-test 50 dan post-test 82 , artinya mengalami kenaikan sebesar 64\%. Jumlah kenaikan kelas eksperimen lebih besar dari kelas kontrol. Selisih kenaikan tersebut sebesar $40 \%$, artinya bahwa media laboratorium virtual Physics Educatin Technology mempengaruhi hasil belajar $40 \%$ lebih baik dari metode biasa.
\end{abstract}

Kata Kunci: Laboratorium Virtual Physics Education Technology; Hasil Belajar; Fisika.

\begin{abstract}
This study was conducted in the year 2017/2018 lesson in class XII of Madrasah Aliyah Al Muhajirin Tugumulyo. The purpose of this research is to determine the influence of the virtual laboratory of Physics Education Technology on student Physics learning outcomes. The population used in this study was all students of the class XII IPA MA Al Muhajirin Tugumulyo amounting to 95 students. Meanwhile, the object or sample of this research is taken using the convenience sampling technique, which is a sample control in the form of matching samples. The sample was used in the class XII ibn Meskavayh as a class given the treatment, and class XII Al Idris as a comparative class or control class. Data analysis techniques using infrential analyzers are the test of the and test $T$ statistics. The results obtained the average value of the control class namely 65 Pre-Test and Post-Test 68 means that the increase in learning outcomes by $24 \%$ of the average results of Pre-Test. As for the experiment class the average value of the learning outcomes on the Pre-Test is 50 and PostTest 82 means an increase of 64\% this means that the increase in experiment classes is greater than the control class. The difference of the increment is $40 \%$.
\end{abstract}

Keywords: Physics Education Technology Virtual Labs; Learning Outcomes; Physics. 
Edutainment : Jurnal Ilmu Pendidikan dan Kependidikan

Volume 7 Nomor 2 Edisi Juli-Desember 2019

\section{PENDAHULUAN}

Fisika adalah ilmu yang berkaitan dengan eksperimen dan pengamatan gejala-gejala fisis di alam semesta. Pada masa periode kedua atau periode kebangkitan metode eksperimen mulai berkembang dengan pesat. Kaidah, asas dan hukum yang mulanya hanya diterima saja, mulai pada masa periode kedua kaidah, asas dan hukum dibuktikan kebenarannya lewat eksperimen. Dalam periode ini muncul penemuan-penemuan baru yang cukup fundamental dalam bidang fisika. Penemu-penemu tersebut diantaranya yaitu penemuan yang dilakukan oleh Galileo. Galileo Galilei hidup pada tahun 1564 - 1642 adalah seorang yang berpengetahuan luas dan dikenal sebagai bapak fisika eksperismental. Penemuan Galileo yaitu membuat suatu teleskop, dengan teleskop ini Galileo berhasil membuat penemuanpenemuan yang fundamental.

Selain eksperimen yang dilakukan Galileo pada tahun 1831, seorang ilmuan Inggris bernama Michael Faraday berhasil melakukan eksperimen bahwa medan magnet yang berubah-ubah dapat menimbulkan arus listrik atau induksi elektromagnetik (Giancoli, 2001). Sejak penemuan Michael Faraday tersebut, penemuannya dianggap sebagai pembuka jalan dalam bidang kelistrikan. Temuan tersebut terus dikembangkan oleh para ilmuan sampai saat ini melalui eksperimen, karena salah satu proses penting dalam fisika didasarkan pada gejala-gejala fisis yang dapat dijelaskan melalui observasi dan eksperimen (Fahrudin, 2018). Kurikulum fisika di tingkat SMA (Sekolah Menengah Atas) bahwa kegiatan praktikum di laboratorium sangat dibutuhkan guna menunjang keberhasilan dalam pembelajaran (Aktamis dan Acar, 2010). Keberhasilan kegiatan praktikum di laboratorium sangat bergantung pada peran seorang guru dan tidak mudah untuk menyelenggarakannya, karena terdapat berbagai kendala untuk melakukan kegiatan praktikum di laboratorium sekolah, seperti waktu yang sangat terbatas dan alat-alat praktikum yang sudah tidak dapat digunakan lagi atau tidak berfungsi dengan baik (Duban, dkk, 2019).

Seiring dengan berkembangnya zaman eksperimen yang tadinya hanya dilakukan di laboratorium kini mulai dikembangkan ke dalam bentuk laboratorium virtual, terutama untuk meningkatkan pengetahuan siswa di sekolah. Laboratorium virtual merupakan suatu media berbasis komputer yang berisi simulasi kegiatan di laboratorium fisika yang dibuat untuk menggambarkan reaksi-reaksi yang mungkin tidak dapat terlihat pada keadaan nyata (Hermansyah, dkk, 2015). Sedangkan menurut (Herga, dkk 2016) virtual laboratorium adalah simulasi 


\section{Edutainment : Jurnal Ilmu Pendidikan dan Kependidikan}

Volume 7 Nomor 2 Edisi Juli-Desember 2019

interaktif yang dapat menjelaskan konsep abstrak menjadi mudah dimengerti dan dapat mengurangi miskonsepsi dalam pembelajaran. Selain itu, kelebihan virtual laboratorium menurut (Gonzalez, dkk, 2017) adalah sebagai alternatif yang populer, karena lebih fleksibel, aman, mudah diatur, bersih, hemat biaya, dan cepat daripada eksperimen fisik atau langsung. Reaksi-reaksi fisika yang tidak dapat terlihat dalam kehidupan nyata secara langsung seperti arus listrik, garisgaris medan magnet, partikel kecil yang tidak mampu dilihat oleh mata secara langsung. Melalui pembelajaran virtual laboratorium reaksi-reaksi fisika yang sifatnya abstrak mampu digambarkan atau divisualisasikan, sehingga membuat siswa lebih memahami materi pembelajaran. Listrik merupakan kebutuhan pokok bagi manusia terutama di era moderen. Untuk itu materi kelistrikan merupakan materi yang sangat penting untuk dipelajari di sekolah.

Menurut (Mupelita, 2019) salah satu cara untuk mencapai keberhasilan dalam pembelajaran adalah dengan menggunakan metode yang tepat, serta pembelajarannya yang menyenangkan, dan tidak membosankan dalam setiap proses pembelajaran, sehingga siswa termotivasi untuk mengeksplor pengetahuannya dari berbagai sumber. Sedangkan hasil belajar menurut (Paolini, 2015) adalah berbagai macam kemampuan, seperti pengetahuan atau nilai yang dapat diukur dan dimiliki siswa setelah menerima pengalaman belajarnya.

Sementara itu, laboratorium virtual merupakan suatu media berbasis komputer yang berisi simulasi kegiatan di laboratorium fisika yang dibuat untuk menggambarkan reaksi-reaksi yang mungkin tidak dapat terlihat pada keadaan nyata. Pada penelitian ini Laboratorium virtual yang digunakan adalah simulasi interaktif PhET (Physics Education Technology). PhET adalah sebuah aplikasi gratis yang dikembangkan oleh Universitas Colorado. PhET adalah laboratorium virtual yang didalamnya terdapat berbagai simulasi virtual interaktif, seperti praktikum di laboratorium fisika. Penggunaan laboratorium virtual PhET pada komputer sangatlah mudah. Dalam penggunaan laboratorium virtual $\mathrm{PhET}$, komputer yang digunakan harus sudah menginstal aplikasi Java, karena laboratorium virtual PhET dibuat dalam bentuk Java. Salah satu contoh simulasi virtual yang terdapat di dalam aplikasi $\mathrm{PhET}$ ditunjukkan pada gambar 1 berikut ini: 
Edutainment : Jurnal Ilmu Pendidikan dan Kependidikan

Volume 7 Nomor 2 Edisi Juli-Desember 2019

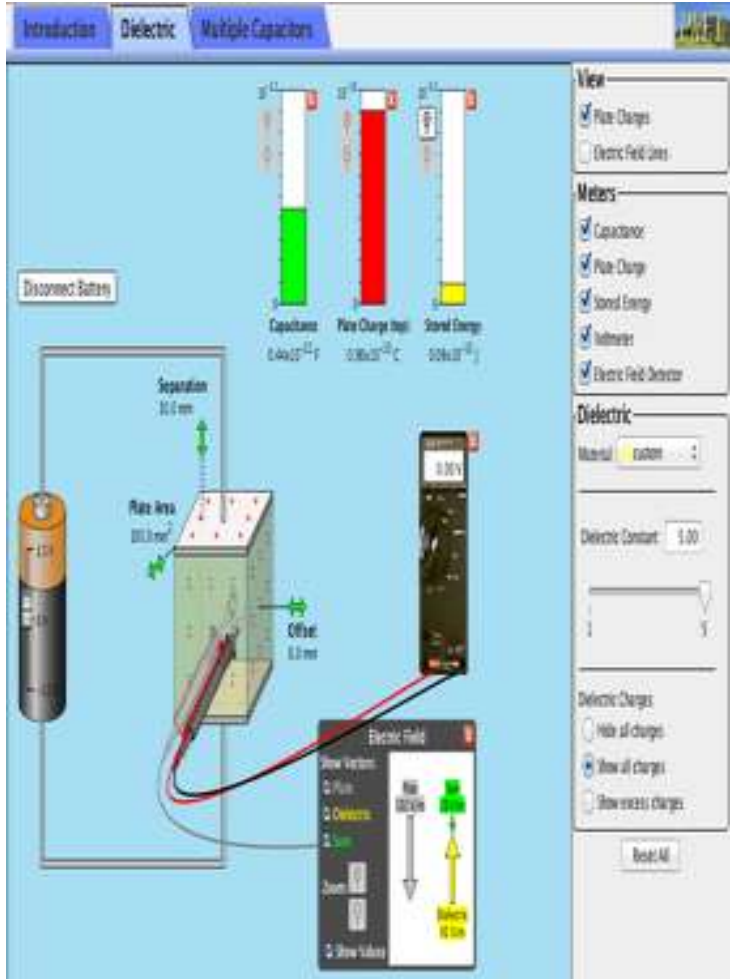

Gambar 1. Aplikasi Laboratorium Virtual PhET pada Materi Listrik Statis

\section{METODE PENELITIAN}

Kuasi eksperimen digunakan sebagai desain penelitian ini dengan kelompok non ekuivalen. Menurut (Setyosari, 2015) bentuk penelitian dengan desain non ekuivalen yaitu berupa pemberian perlakuan pre-test dan post-test (untreated kontrol group with pre-test and post-test design). Bentuk dari desain non ekuivalen yaitu pemberian tindakan terhadap satu atau beberpa variabel yang dimanipulasi agar dapat mempelajari pengaruh setiap variabel terhadap variabel terikat atau pengaruh yang disebabkan adanya interaksi dari beberapa variabel. Menurut (Fraenkel \& Wallen, 2009) desain non ekuivalen dapat digambarkan pada gambar 2 sebagai berikut:

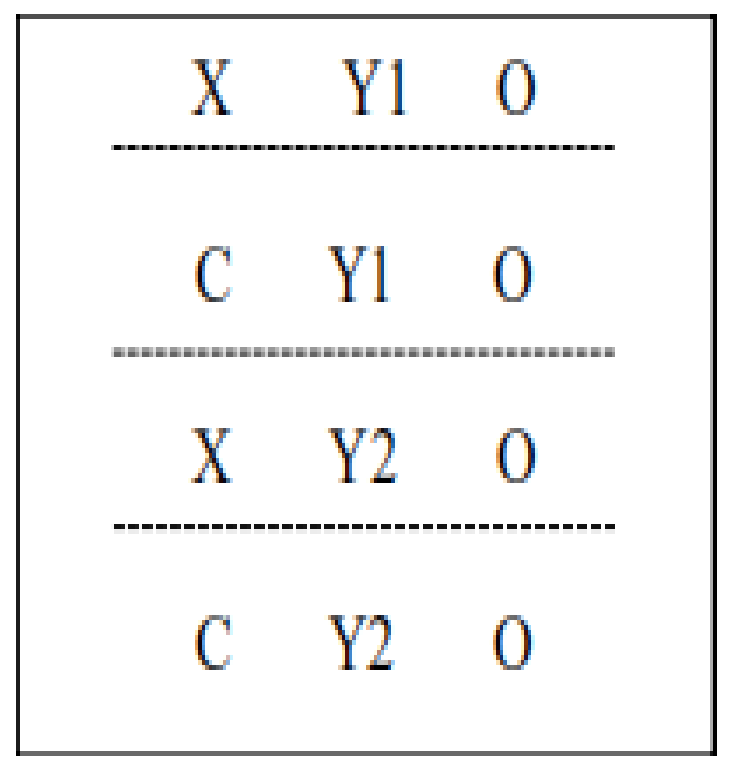

Gambar 2. Desain Penelitian Non Ekuivalen

Keterangan:

$\mathrm{X}$ : Kelas eksperimen diberikan treatment berupa pembelajaran fisika dengan menggunakan media laboratorium virtua PhET.

C : Kelas kontrol sebagai pembanding yang diberikan berupa pembelajaran fisika dengan metode konvensional.

Y1 : Pre - Test

Y2 : Post - Test

$\mathrm{O}$ : Hasil tes belajar setelah diberikan perlakuan untuk pre-test dan posttest.

\section{Populasi dan sampel}

Populasi penelitian ini seluruh siswa kelas XII IPA MA Almuhajirin Tugumulyo yang berjumlah 95 siswa, dan dibagi menjadi empat kelas. Data populasi siswa kelas XII MA Almuhajirin ditunjukan pada tabel 1 berikut ini: 
Edutainment : Jurnal Ilmu Pendidikan dan Kependidikan

Volume 7 Nomor 2 Edisi Juli-Desember 2019

Tabel 1. Populasi Siswa Kelas XII MA Almuhajirin

\begin{tabular}{cc}
\hline Kelas & Jumlah Siswa \\
\hline XII (Ibnu Miskawaih) & 24 \\
\hline XII (Farabi) & 23 \\
\hline XII (Al Idris) & 24 \\
\hline XII (Ibnu Sina) & 24 \\
\hline Total & 95 \\
\hline Sedangkan sampel adalah bagian dari
\end{tabular}

populasi yang dapat mewakili atau representatif (Sugiyono, 2014). Pengambilan sampel dalam penelitian ini dilakukan secara convenience sampling yaitu dengan pengontrolan sampel berupa sampel sepadan. Sampel penelitian ini yaitu kelas XII Ibnu Miskawaih sebagai kelas yang diberikan treatment (kelas eksperimen), dan kelas XII Al Idris sebagai kelas pembanding atau kelas kontrol. Sedangkan teknik pengumpulan data yang digunakan dalam penelitian ini tes objektif.

\section{Analisis Inferensial}

Analisis inferensial adalah analisis yang digunakan untuk menguji hipotesis dalam penelitian (Teja dan Reddy, 2018). Sebelum dilakukan uji hipotesis dilakukan uji prasyarat, yakni uji normalitas dan uji homogenitas varian. Uji normalitas dalam penelitan ini menggunakan KolmogorovSmirnov. Sedangkan uji homogenitas varian dihitung menggunakan uji-F. Setelah dilakukan uji prasyarat dan didapatkan data berdistribusi normal dan homogen, maka dapat dilakukan uji inferensial untuk pengujian hipotesis. Uji hipotesis pada penelitian ini menggunakan analisis uji t statistik.

\section{Uji Hipotesis}

Untuk melakukan pengujian Separated Varians dan Polled Varians atau uji dua pihak, langkah pertama yaitu merumuskan hipotesis secara statistik. Perumusan hipotesis statistik yang digunakan dalam penelitian ini sebagai berikut:

$\mathrm{H} 0: \mu \mathrm{A} 1=\mu \mathrm{A} 2$

$\mathrm{H} 1: \mu \mathrm{A} 1 \neq \mu \mathrm{A} 2$

$\mathrm{H} 0$ : Tidak terdapat perbedaan hasil belajar fisika antara siswa yang diajar dengan menggunakan media laboratorium virtual PhET dengan media konvensional di MA Almuhajirin Tugumulyo.

H1 : Terdapat perbedaan hasil belajar fisika antara siswa yang diajar dengan menggunakan media laboratorium virtual PhET dengan media konvensional di MA Almuhajirin Tugumulyo.

Pada penelitian ini uji hipotesis yang digunakan untuk analisis yaitu uji $\mathrm{t}$ statistik pada taraf signifikan $\alpha=0,05$. 
Edutainment : Jurnal Ilmu Pendidikan dan Kependidikan

Volume 7 Nomor 2 Edisi Juli-Desember 2019

\section{HASIL DAN PEMBAHASAN}

Dalam penelitian ini objek penelitian (sampel) diberikan perlakuan yang berbeda yaitu menggunakan media laboratorium virtual PhET untuk kelas ekeperiman (kelas ibnu miskawaih) dan metode konvensional untuk kelas kontrol (kelas Al Idris). Setiap kelas sebelum diberikan treatment atau perlakuan diberikan tes objektif (pre-test) untuk mengetahui kemampuan awal siswa. Sedangkan setalah diberikan perlakuan atau treatment objek penelitian kembali diberikan tes objektif untuk mengetahui perbedaan hasil belajar dari setiap kelas. Adapun hasil belajar untuk kelas eksperimen dan kelas kontrol pada pre-test dan post-test ditunjukkan pada tabel 2 berikut ini:

Tabel 2. Data Hasil Pre-Test dan Post-Test Kelas Kontrol dan Eksperimen

\begin{tabular}{cccccc}
\hline Rentang & \multicolumn{5}{c}{ Pre-Test } \\
\cline { 2 - 6 } & \multicolumn{3}{c}{ Eksperimen } & \multicolumn{2}{l}{ Kontrol } \\
\cline { 2 - 6 } & F & $\%$ & F & $\%$ & Katagori \\
\hline $86-100$ & 1 & 4 & 1 & 4 & $\begin{array}{c}\text { Sangat Baik } \\
\text { (SB) }\end{array}$ \\
\hline $66-85$ & 14 & 58 & 15 & 67 & Baik(B) \\
\hline $56-65$ & 9 & 38 & 8 & 29 & Cukup (C) \\
\hline $46-55$ & 0 & 0 & 0 & 0 & Kurang (D) \\
\hline Jumlah & 24 & 100 & 24 & 100 \\
\hline Rentang & \multicolumn{5}{c}{ Post-Test }
\end{tabular}

\begin{tabular}{cccccc} 
& \multicolumn{3}{c}{ Eksperimen } & \multicolumn{2}{c}{ Kontrol } \\
\cline { 2 - 6 } & $\mathrm{F}$ & $\%$ & $\mathrm{~F}$ & $\%$ & Katagori \\
\hline $86-100$ & 3 & 13 & 1 & 4 & $\begin{array}{c}\text { Sangat Baik } \\
\text { (SB) }\end{array}$ \\
\hline $66-85$ & 20 & 83 & 17 & 71 & Baik (B) \\
\hline $56-65$ & 1 & 4 & 6 & 25 & Cukup (C) \\
\hline $46-55$ & 0 & 0 & 0 & 0 & Kurang (D) \\
\hline Jumlah & 24 & 100 & $! 4$ & 100 & \\
\hline
\end{tabular}

Berdasarkan tabel 2 di atas diperoleh data sebaran nilai pre-test dan post-test sebagai berikut: Kelas kontrol didapatkan nilai nilai $67 \%$ pada katagori baik untuk pre-test, dan $71 \%$ pada post-test. Sedangkan kelas eksperimen didapatkan nilai 58\% pada katagori baik untuk pre-test dan $83 \%$ post-test. Berdasarkan data tersebut dapat disimpulkan bahwa hasil belajar kedua kelas setelah diberi perlakuan berbeda. Selanjutnya sebelum dilakukan uji hipotesis sebelumnya harus memenuhi uji prasyarat, yakni uji normalitas dan homogenitas. Adapun hasil uji normalitas ditunjukkan pada tabel 3 berikut ini:

Tabel 3. Data Hasil Uji Normalitas

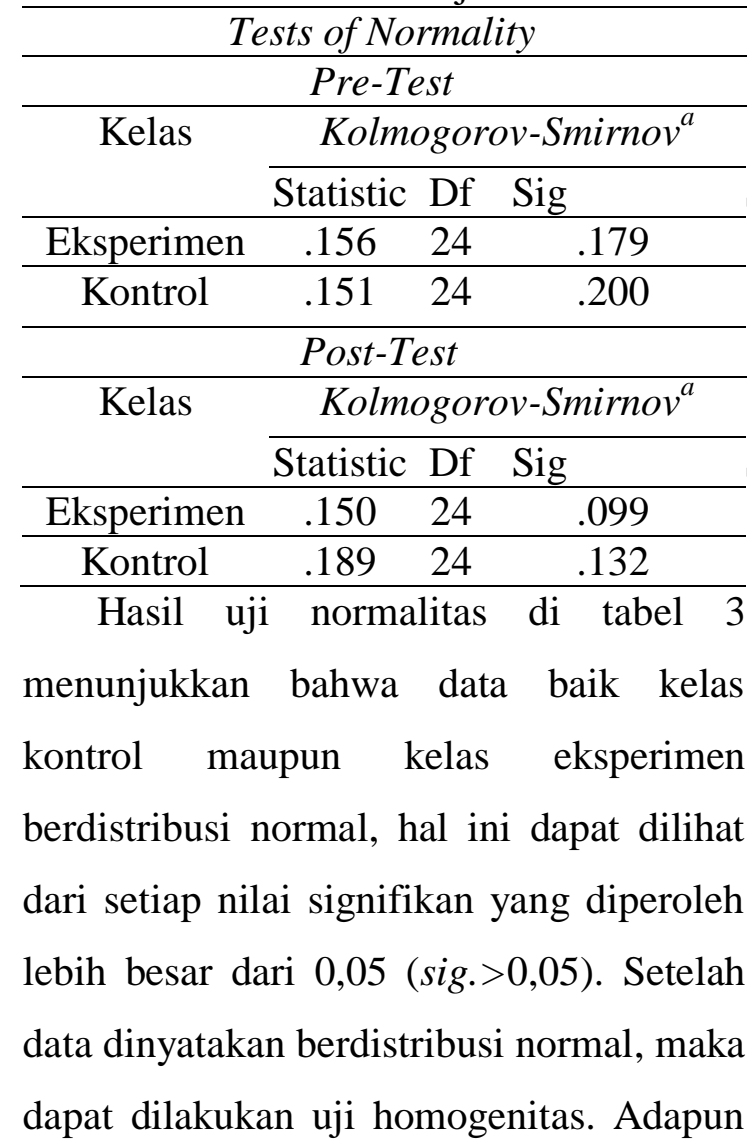


Edutainment : Jurnal Ilmu Pendidikan dan Kependidikan

Volume 7 Nomor 2 Edisi Juli-Desember 2019

hasil uji homogenitas ditampilkan pada tabel 4 sebagai berikut:

Tabel 4. Hasil Uji Homogenitas Test of Homogeneity of Variances

\begin{tabular}{cccc}
\multicolumn{4}{c}{ Pre-Test } \\
\hline Levene Statistic & df1 & df2 & Sig. \\
3.168 & 1 & 46 & .082 \\
\hline \multicolumn{4}{c}{ Post-Test } \\
\hline Levene Statistic & df1 & df2 & Sig. \\
3.061 & 1 & 46 & .087 \\
\hline
\end{tabular}

Tabel 4 di atas menunjukkan hasil dari uji homogenitas menggunakan SPSS untuk mencari hasil dari uji Levene Statistic. Hasil uji Levene Statistic diperoleh nilai sebesar 3,168 dan signifikansi sebesar 0,082. Apabila nilai dari signifikansi dan Levene Statistic lebih besar dari 0,05 maka data yang digunakan sebagai sampel penelitian bersifat homogen.

Setelah data dari sampel penelitian diketahui berdistribusi normal dan homogen, maka memenuhi syarat untuk dilakukan uji hipotesis. Uji hipotesis dalam penelitian ini menggunakan uji $\mathrm{t}$ statistik. Adapun hasil dari uji $t$ diperlihatkan pada tabel 5 berikut ini:

Tabel 5. Hasil Uji t Pre-Test dan Post-Test Kelas Kontrol dan Eksperimen

\begin{tabular}{ccccc}
\hline Data & $\mathrm{T}_{\text {hitung }}$ & df & $\begin{array}{c}\text { Sig. } \\
(2- \\
\text { tailed) }\end{array}$ & Keterangan \\
\hline $\begin{array}{c}\text { Pre- } \\
\text { Test }\end{array}$ & $-0,55$ & 46 & 0,542 & $\begin{array}{c}\text { Sig. (2-tailed) } \\
>0,05 \text { (tidak } \\
\text { ada perbedaan } \\
\text { yang } \\
\text { signifikan) }\end{array}$ \\
\hline $\begin{array}{c}\text { Post- -8,38 } \\
\text { test }\end{array}$ & 46 & 0,00 & $\begin{array}{c}\text { (ada } \\
\text { perbedaan } \\
\text { yang } \\
\text { signifikan) }\end{array}$ \\
\hline
\end{tabular}

Berdasarkan tabel 5 didapatkan hasil uji t statistik untuk pre-test dengan nilai signifikansi 0,542 atau lebih besar dari $0,05(0,542>0,05)$, artinya data hasil pretest sebelum diberi perlakuan tidak ada perbedaan hasilnya. Sedangkan pada posttes nilai signifikansi yaitu 0,00 atau lebih kecil dari taraf ukuran signifikansi 0,05 $(0,00<0,05)$, artinya bahwa data setelah diberikan perlakuan memiliki perbedaan signifikan. Dari hasil tersebut bahwa $\mathrm{H}_{0}$ ditolak dan $\mathrm{H}_{1}$ diterima, maka dari hasil penelitian ini terdapat perbedaan hasil belajar fisika antara siswa yang diajar dengan menggunakan media laboratorium virtual PhET dengan media konvensional di MA Almuhajirin Tugumulyo. Perbedaan tersebut dapat dijelaskan dalam gambar 3 berikut ini:

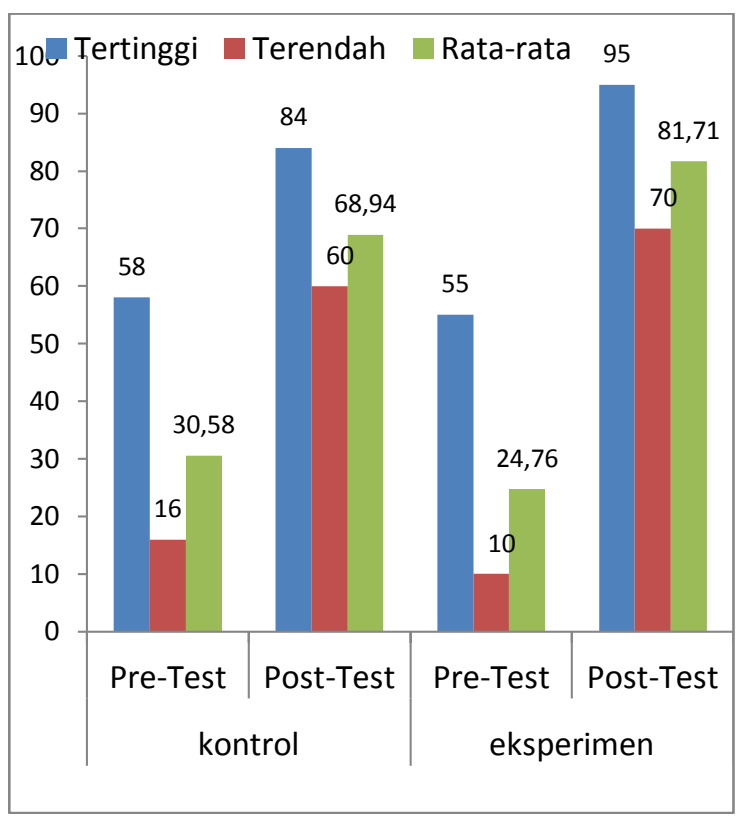

Gambar 3. Data Nilai Rata-rata, Tertinggi, Terendah Kelas Kontrol dan Eksperimen pada Pre-Test dan Post-Test 
Edutainment : Jurnal Ilmu Pendidikan dan Kependidikan

Volume 7 Nomor 2 Edisi Juli-Desember 2019

Dari gambar 3 diketahui hasil pre-test nilai rata-rata kelas kontrol 65 dan posttest 68, artinya mengalami kenaikan hasil belajar sebesar $24 \%$. Sedangkan pada kelas eksperimen nilai rata-rata hasil belajar pada pre-test 50 dan post-test 82, mengalami kenaikan sebesar 64\%, hal ini berarti jumlah kenaikan kelas eksperimen lebih besar dari kelas kontrol.

\section{KESIMPULAN DAN SARAN}

Berdasarkan hasil analisis data pada pengaruh laboratorium virtual PhET di kelas XII Almuhajirin Tugumulyo yaitu kelas eksperimen (Ibnu Miskawai) dan metode konvensional (Al Idris) dapat disimpulkan sebagai berikut:

Terdapat perbedaan hasil belajar fisika antara siswa yang diajar dengan menggunakan media laboratorium virtual PhET dengan media konvensional di MA Almuhajirin Tugumulyo.

Hasil dari masing-masing treatment atau perlakuan dari kelas kontrol dan eksperimen mengalami kenaikan, akan tetapi pada kelas eksperimen mengalami kenaikan yang lebih signifikan dari kelas kontrol. Selisih kenaikan tersebut sebesar $40 \%$ atau dapat diartikan bahwa media laboratorium virtual $\mathrm{PhET}$ mempengaruhi hasil belajar $40 \%$ lebih baik dari metode biasa (konvensional).

\section{DAFTAR PUSTAKA}

Aktamis, H \& Acar, E. (2010). The effect of "laboratory practices in science teaching" course on development of prospective science teachers' selfregulation skills. Procedia Social and Behavioral Sciences. Vol 2 Hal 5549-5553.

Duban, N., Aydoğdu, B., \& Yüksel, A. (2019). Classroom Teachers' Opinions on Science Laboratory Practices. Universal Journal of Educational Research. Vol 7 No. 3 Hal 772-780.

Fahrudin, A. (2018) Development of Physics Summary Book as a Smartphone-Based Application and Its Effect on Elasticity Learning Achievement. Kasuari: Physics Education Journal. Vol 1 no. 1. Hal 22-33.

Frankel, J.P. \& Wallen N.E. (2009). How To Design and Evaluate Research in Education. New York: McGraw-Hill.

Giancoli, D. (1998). Physics Fifth Edition Part 2. Alih Bahasa Hanum, Y dan Arifin, I. 2001. Fisika Edisi Kelima Jilid 2. Jakarta: Erlangga

Gonz’alez, J. D., Escobar, J.H., S’anchez , H., De la Hoz, J \& Beltr'an, J. R. (2017). 2D and 3D virtual interactive laboratories of physics on Unity platform. Journal of Physics: Conf. Serie, Vol 935 No 012069. 
Herga, N.R., Čagran, B. \& Dinevski, D. (2016). Virtual Laboratory in the Role of Dynamic Visualisation for Better Understanding of Chemistry in Primary School. Eurasia Journal of Mathematics, Science \& Technology Education, Vol 12. No 3 Hal 593-608. Hermansyah, Gunawan, \& Herayanti, L. (2015). Pengaruh Penggunaan Laboratorium Virtual Terhadap Penguasaan Konsep dan Kemampuan Berpikir Kreatif Siswa Pada Materi Getaran Dan Gelombang. Jurnal Pendidikan Fisika dan Teknologi. Volume I No 2 Hal 97 -102.

Mupelita, G. (2019). Peningkatan Hasil Belajar Siswa Melalui Penerapan Kolaborasi Media Picture Dengan Metode Eksperimen. Edutainment: Jurnal Ilmu Pendidikan dan Kependidikan. Volume 7 Nomor 1. Hal 45-60.

Paolini, A. (2015). Enhancing Teaching Effectiveness and Student Learning Outcomes. The Journal of Effective Teaching, Vol. 15, No.1, Hal 20-33.

Setyosari, P. 2015. Metode Penelitian

Pendidikan \& Pengembangan. Jakarta:

Kencana Prenada media Group.

Sugiono. (2014). Metodologi Penelitian

Pendidikan. Bandung: Alfabeta.
Teja, S.G.S \& Reddy, H. P (2018). Inferential Statistics for Data Science. International Journal for Research in Applied Science \& Engineering Technology (IJRASET), Vol 6 No 7 Hal 416-418. 